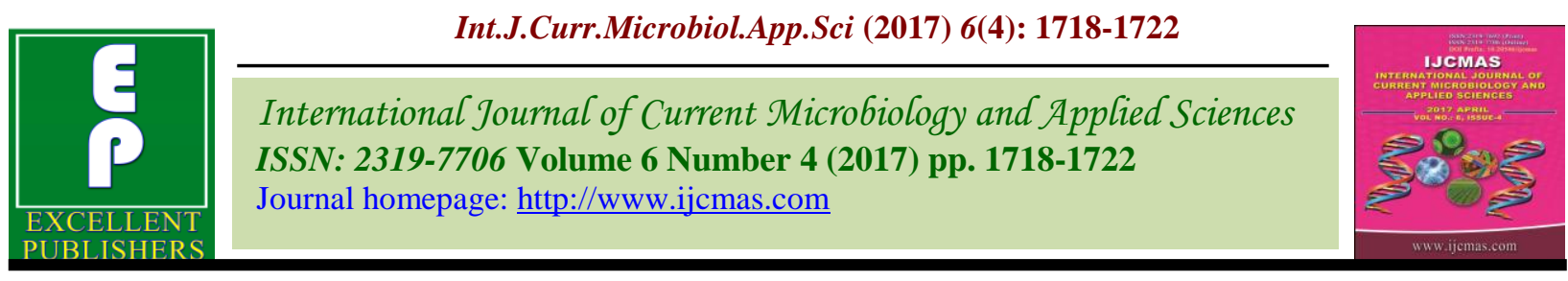

Original Research Article

https://doi.org/10.20546/ijcmas.2017.604.206

\title{
Impact of Fertigation and Target Yield Levels on Soil Microbial Biomass and Cane Yield of Ratoon Sugarcane
}

\author{
Basavaraj Patil*, S.M. Hiremath, B.T. Nadagouda and M.P. Potdar \\ Department of Agronomy, University of Agricultural Sciences, Dharwad, \\ Karnataka-580005, India \\ *Corresponding author
}

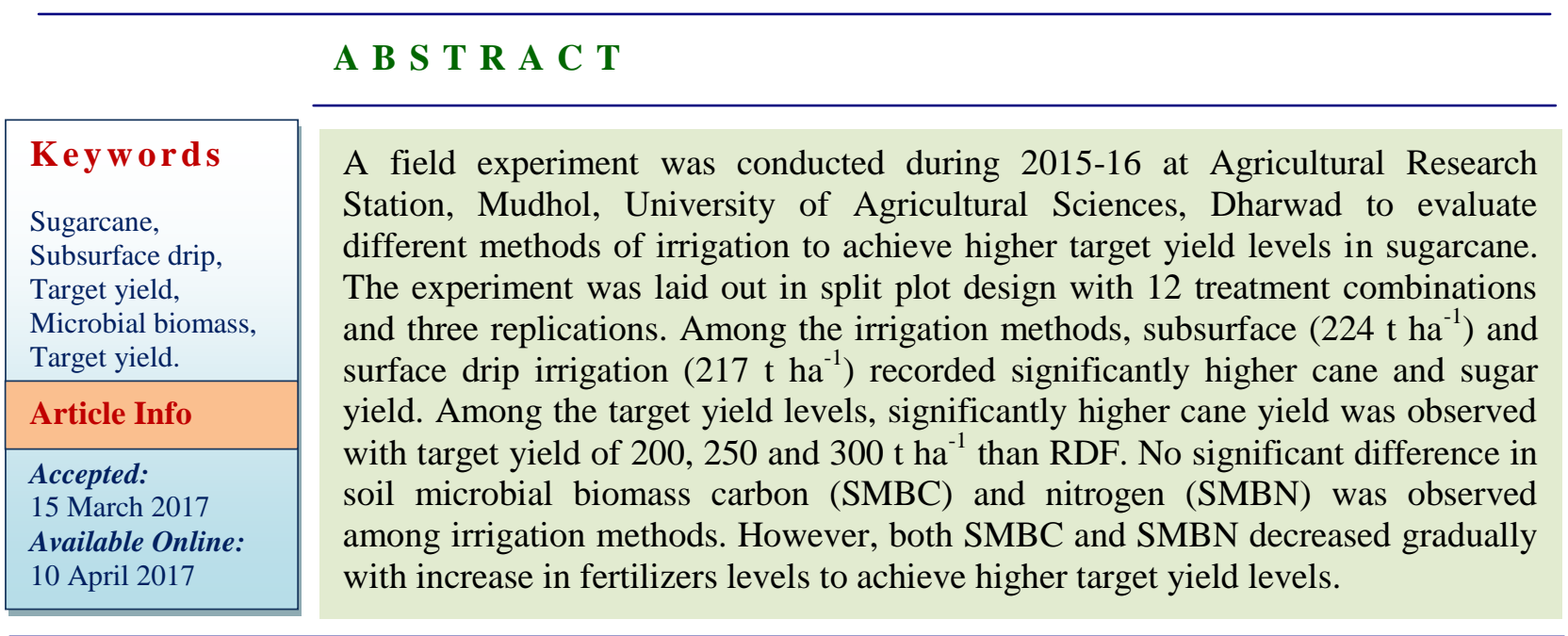

\section{Introduction}

In India, sugarcane alone covers 5.14 million hectare area in India with a production of 359.33 million tones (Anon., 2015). Sugarcane being a long duration and huge biomass accumulating crop removes substantial amount of plant nutrients from the soil. There exists a huge regional disparity in fertilizer use and the consumption of plant nutrients. All these point out to greater opportunity for using more balanced fertilizers for enhancing cane productivity, produce quality and maintaining system sustainability. The analysis of sugarcane productivity trends during the recent years reveals that the cane yield throughout the country is almost stagnant or declining.
Besides socio economic constraints, the most significant reason for the yield decline in an intensive cultivation is inadequate and imbalanced water and nutrient supply. Amongst the factors of production inputs, nutrients and water have played a key role in increasing production of sugarcane in India. To get maximum benefit and reduce nutrient losses from fertilizers, they must be applied in the right quantity, source and combination at the right time using the right method. Indian sugarcane farmers are adopting surface irrigation practices. This leads to excess usage and wastage of water may lead to form salty and saline soils. Application of water and nutrient at the time of actual need through 
subsurface and surface drip with right quantity of water to wet the effective root zone soil is the proper irrigation management system to save the precious water and nutrient. Under these circumstances, innovative technologies such as site specific nutrient management (SSNM) will have to be put to use at farm level for enhancing production with improved water and nutrient use efficiency to realize higher yield levels in sugarcane. The soil microbial biomass is fundamental to maintaining soil functions because it represents the main source of soil enzymes that regulate transformation processes of elements in soils. The SOC stock is comprised of labile or actively cycling pool. Labile $\mathrm{C}$ pool is the fraction of SOC with rapid turnover rates. Some carbon pools like $\mathrm{CO} 2$ evolution, soil microbial biomass carbon, soil microbial biomass nitrogen, water soluble carbon, acid hydrolysable carbohydrates are used as an indicator of soil quality. Soil microbial biomass study reflects energy flow, acts as an agent of transformation of all substances and reflects on a labile pool of $\mathrm{C}, \mathrm{N}, \mathrm{P}, \mathrm{S}$ and micronutrients (Mishra et al., 2008). Hence, keeping these points in view a field experiment was conducted to know the impact of methods of irrigation and target yield levels on sugarcane yield and microbial biomass.

\section{Materials and Methods}

Field experiment was conducted at Agricultural Research Station, Mudhol, University of Agricultural Sciences, Dharwad, during 2015-16 seasons under irrigated condition to study the impact of methods of irrigation and target yield levels on sugarcane yield and microbial biomass in ratoon sugarcane. The experiment was laid out in split plot design consisting of 3 main plots (Sub surface drip, surface drip and furrow irrigation) and 4 sub plots (target yield of 200, 250, $300 \mathrm{t} \mathrm{ha}^{-1}$ and RDF) with three replications. Prior to experiment the whole experimental field was divided into 20 X 20 $\mathrm{m}$ grids and soil samples were drawn from each grid to know the soil spatial variability for major nutrients. Nutrient status for the entire study area was low in nitrogen, low in phosphorus and high in potash. Nutrient requirement was worked out by uptake studies as recommended by Zende, 1998. Entire $\mathrm{P}_{2} \mathrm{O}_{5}$ was applied as basal and $\mathrm{N}$ and $\mathrm{K}_{2} \mathrm{O}$ in 8 equal splits scheduled at monthly intervals. The nutrients were supplied in the form of water soluble urea, phosphoric acid and muriate of potash in drip irrigation and single super phosphate as $\mathrm{P}$ source in furrow irrigation. The surface and sub surface drip systems were installed after land and seed bed preparation. The sub lines are installed at intermittent distances and drip lines are laid between rows and covered by ridger in sub surface drip. In surface drip irrigation block drip lines are remained above the ground along with crop rows. The observations on all yield parameters and yield were recorded as per the standard procedure and were statistically analyzed as per the methodology suggested by Gomez and Gomez (1984). Soil microbial biomass carbon and soil microbial nitrogen was estimated by chloroform fumigation and extraction method, Carter (1991).

\section{Results and Discussion}

\section{Cane and Sugar yield}

Cane yield of sugarcane was significantly influenced by methods of irrigation (Table 1). Significantly higher cane yield was observed in subsurface drip irrigation (137 $\mathrm{t} \mathrm{ha}^{-1}$ ) and surface drip irrigation $\left(125 \mathrm{t} \mathrm{ha}^{-1}\right)$ over furrow method of irrigation. The furrow method of irrigation recorded significantly lower cane yield $\left(96 \mathrm{t} \mathrm{ha}^{-1}\right)$. The increase in cane yield was to the extent of 42.7 and 30.2 per cent 
respectively over furrow irrigation. Sugar yield is a function of cane yield and commercial cane sugar per cent. Higher sugar yield was also observed with subsurface $\left(16.91 \mathrm{t} \mathrm{ha}^{-1}\right)$ and surface drip $\left(15.51 \mathrm{t} \mathrm{ha}^{-1}\right)$ irrigation over furrow method of irrigation.

In the target yield levels, higher cane yield was obtained with the application of nutrients required to achieve target yield of $300 \mathrm{t} \mathrm{ha}^{-1}$ $\left(153 \mathrm{t} \mathrm{ha}^{-1}\right)$ over the lower target yields and RDF. However, yield obtained in $200 \mathrm{t} \mathrm{ha}^{-1}$ and $250 \mathrm{t} \mathrm{ha}^{-1}$ in plant crop was comparable with higher target yield level. Significantly lower cane yield was observed in RDF $(88 \mathrm{t}$ $\mathrm{ha}^{-1}$ ). The increment in cane yield was to the tune of 42.4 per cent over RDF. The results obtained in the present investigation indicated that magnitude of increase in the productivity of sugarcane through target yield approach was significantly higher than the productivity recorded with RDF. The present results are in close agreement with findings of Kadu and Sonar (2007) and Potdar et al., (2014).

Interaction of subsurface drip with $300 \mathrm{t} \mathrm{ha}^{-1}$ target yield level $\left(\mathrm{I}_{1} \mathrm{~S}_{3}\right)\left(179 \mathrm{t} \mathrm{ha}^{-1}\right)$ and surface drip with $300 \mathrm{t} \mathrm{ha}^{-1}$ target yield level $\left(\mathrm{I}_{2} \mathrm{~S}_{3}\right)\left(161 \mathrm{t} \mathrm{ha}^{-1}\right)$ recorded higher cane yield over combination of furrow irrigation with RDF and remain significantly higher over other treatments (Table 1). The yield increment was to the tune of 57.5 per cent in $\mathrm{I}_{1} \mathrm{~S}_{3}$ over $\mathrm{I}_{3} \mathrm{~S}_{4}$. Highest shoot population coupled with efficient conversion of tillers into millable canes at harvest might have contributed to higher cane yield. Since the sugar yield is dependent on cane yield, it followed the similar pattern as the cane yield. A significant increase in cane yield was observed at higher dose of nitrogen and potassium fertilizers. The higher yields in drip may also be resultant of required and continuous availability of soil moisture which was held at field capacity. Increase in sugarcane yield with increase in fertilizer level was also reported by Rajanna and Patil (2003). Further, Raskar and Bhoi (2001) reported that application of straight fertilizers as urea and muriate of potash were the best alternative source of water soluble fertilizers for getting higher productivity in drip fertigation.

\section{Soil microbial biomass carbon and nitrogen (SMBC and SMBN)}

No significant difference in soil microbial biomass carbon (SMBC) and nitrogen (SMBN) was observed among irrigation methods (Table 2). However, both SMBC and SMBN decreased gradually with increase in fertilizers levels to achieve higher target yield levels. RDF $\left(0.41 \mathrm{mg} \mathrm{g}^{-1}\right.$ of soil and $16.90 \mu \mathrm{g}$ $\mathrm{g}^{-1}$ of soil respectively,) and target yield of $200 \mathrm{t} \mathrm{ha}^{-1}\left(0.33 \mathrm{mg} \mathrm{g}^{-1}\right.$ of soil and $13.72 \mu \mathrm{g} \mathrm{g}^{-1}$ of soil respectively,) recorded significantly higher SMBC and SMBN than target yield of $300 \mathrm{tha}^{-1}$ and $250 \mathrm{t} \mathrm{ha}^{-1}$.

Among the interaction of irrigation methods and target yield levels, surface drip with RDF $\left(\mathrm{I}_{2} \mathrm{~S}_{4}\right)$ recorded significantly higher SMBC and SMBN $\left(0.49 \mathrm{mg} \mathrm{g}^{-1}\right.$ of soil and $20.53 \mu \mathrm{g}$ $\mathrm{g}^{-1}$ of soil respectively,) and was on par with all the interactions except $I_{3} S_{3}$. Furrow irrigation with $300 \mathrm{t} \mathrm{ha}^{-1}\left(\mathrm{I}_{3} \mathrm{~S}_{4}\right)$ recorded significantly lower SMBC $\left(0.10 \mathrm{mg} \mathrm{g}^{-1}\right.$ of soil). Similarly, Liu et al., (2013) also reported the decrease in soil microbial biomass with addition of nitrogen fertilizer.

Soil microbial biomass carbon is the most active and dynamic pool of the soil organic matter, function as transient nutrients sinks and are responsible for releasing nutrients from organic matter for use by plants. Management practices which are associated with intensification of agriculture are well known to alter soil microbial biomass and activity. 
Table.1 Cane yield and sugar yield of ratoon sugarcane as influenced by irrigation methods and target yield levels

\begin{tabular}{|c|c|c|c|c|c|c|c|c|}
\hline & \multicolumn{4}{|c|}{ Cane yield $\left(\mathrm{t} \mathrm{ha}^{-1}\right)$} & \multicolumn{4}{|c|}{ Sugar yield $\left(\mathrm{t} \mathrm{ha}^{-1}\right)$} \\
\hline Target yields & $\begin{array}{l}\text { Subsurface } \\
\text { drip }\left(\mathbf{I}_{1}\right)\end{array}$ & $\begin{array}{l}\text { Surface } \\
\text { drip }\left(I_{2}\right)\end{array}$ & $\begin{array}{c}\text { Furrow } \\
\text { irrigation }\left(\mathbf{I}_{3}\right)\end{array}$ & Mean & $\begin{array}{l}\text { Subsurface } \\
\text { drip }\left(\mathbf{I}_{1}\right)\end{array}$ & $\begin{array}{l}\text { Surface } \\
\operatorname{drip}\left(\mathbf{I}_{2}\right)\end{array}$ & $\begin{array}{c}\text { Furrow } \\
\text { irrigation } \\
\left(\mathbf{I}_{3}\right)\end{array}$ & Mean \\
\hline $\mathrm{S}_{2}-250 \mathrm{t} \mathrm{ha}^{-1}$ & 152 & 128 & 102 & 127 & 18.88 & 15.97 & 12.65 & 15.84 \\
\hline $\mathrm{S}_{3}-300 \mathrm{t} \mathrm{ha}^{-1}$ & 179 & 161 & 119 & 153 & 22.24 & 20.22 & 14.75 & 19.07 \\
\hline & & I & $\mathrm{S}$ & $\mathrm{I} \times \mathrm{S}$ & & I & $\mathrm{S}$ & $\mathrm{I} \times \mathrm{S}$ \\
\hline & S. Em. \pm & 2.80 & 5.80 & 10.05 & & 0.35 & 0.73 & 1.26 \\
\hline & $\mathrm{CD}(\mathrm{P}=0.05)$ & 10.99 & 17.25 & $\mathrm{NS}$ & & 1.39 & 2.16 & $\mathrm{NS}$ \\
\hline
\end{tabular}

Table.2 Soil microbial biomass carbon $\left(\mathrm{mg} \mathrm{g}^{-1}\right.$ of soil) and soil microbial biomass nitrogen $\left(\mu \mathrm{g} \mathrm{g}^{-1}\right.$ of soil) as influenced by irrigation methods and target yield levels

\begin{tabular}{|c|c|c|c|c|c|c|c|c|}
\hline & \multicolumn{4}{|c|}{ Soil microbial biomass carbon } & \multicolumn{4}{|c|}{ Soil microbial biomass nitrogen } \\
\hline Target yields & $\begin{array}{c}\text { Subsurface } \\
\text { drip }\left(I_{1}\right)\end{array}$ & $\begin{array}{c}\text { Surface drip } \\
\left(\mathbf{I}_{2}\right)\end{array}$ & $\begin{array}{c}\text { Furrow } \\
\text { irrigation }\left(\mathbf{I}_{3}\right)\end{array}$ & Mean & $\begin{array}{c}\text { Subsurface } \\
\text { drip }\left(\mathbf{I}_{1}\right)\end{array}$ & $\begin{array}{l}\text { Surface } \\
\text { drip }\left(\mathbf{I}_{2}\right)\end{array}$ & \begin{tabular}{|c|} 
Furrow \\
irrigation $\left(\mathbf{I}_{3}\right)$
\end{tabular} & Mean \\
\hline $\mathrm{S}_{1}-200 \mathrm{t} \mathrm{ha}^{-1}$ & 0.28 & 0.43 & 0.28 & $\mathbf{0 . 3 3}$ & 11.73 & 17.90 & 11.53 & 13.72 \\
\hline $\mathrm{S}_{2}-250 \mathrm{t} \mathrm{ha}^{-1}$ & 0.25 & 0.19 & 0.19 & 0.21 & 10.37 & 7.87 & 7.97 & 8.73 \\
\hline $\mathrm{S}_{3}-300 \mathrm{t} \mathrm{ha}^{-1}$ & 0.23 & 0.22 & 0.10 & 0.18 & 9.60 & 9.07 & 4.33 & 7.67 \\
\hline $\mathrm{S}_{4}$ RDF & 0.42 & 0.49 & 0.31 & $\mathbf{0 . 4 1}$ & 17.37 & 20.53 & 12.80 & 16.90 \\
\hline \multirow[t]{2}{*}{ Mean } & $\mathbf{0 . 2 9}$ & $\mathbf{0 . 3 3}$ & 0.22 & 0.28 & 12.27 & 13.84 & 9.16 & 11.76 \\
\hline & I & $\mathbf{S}$ & \multicolumn{2}{|l|}{ I $\times S$} & & I & $\mathrm{S}$ & $\mathrm{Ix} \mathrm{S}$ \\
\hline S. Em. \pm & 0.04 & 0.05 & \multicolumn{2}{|c|}{0.09} & & 1.80 & 2.28 & 3.95 \\
\hline $\mathrm{CD}(\mathrm{P}=0.05)$ & NS & 0.16 & \multicolumn{2}{|c|}{ NS } & & NS & 6.78 & NS \\
\hline
\end{tabular}


In the present investigation, soil microbial biomass carbon decreased gradually as increase in target yield levels was observed. It might be due to increased dosage which inhibits the survival of microbes due to osmotic stress created by fertilizers (Jeya et al., 2011).

Based on the results of the study it is concluded that both subsurface and surface drip irrigation will help to increase the cane and sugar yield besides saving huge quantity of water. However, integrated nutrient management practice with drip irrigation method could be evaluated to sustain the productivity of system and soil microbial biomass.

\section{References}

Anonymous. 2015. Annu. Rep., 2014-15. Sugarcane Breeding Institute, Coimbatore.

Carter, M.R. 1991. Ninhydrin-reactive N released by the fumigation-extraction method as a measure of microbial biomass under field conditions. Soil Biol. Biochem., 23: 139-143.

Gomez, K.A. and Gomez, A.A. 1984. Statistical Procedure for Agri. Res., An International Rice Research Institute Book, A. Wiley-inter Science, John Wiley and Sons Inc. New York, United States of America, p. 639.

Jeya, B.M., Balachandar, D., Narayanan, R. and Kumar, K. 2011. Impact of fertigation on soil microbial community and enzyme activities cropped with maize (cultivar. COMH1) under precision farming system. Madras
Agric. J., 98(1-3): 84-88.

Kadu, P.P. and Sonar, K.K. 2007. Yield targeting in seasonal sugarcane by conjoint use of chemical fertilizers and organic manures. Asian J. Soil Sci., 2(2): 13-15.

Liu, L., Zhang, T., Gilliam, F. S., Gundersen, P., Zhang, W., Chen, H. and Mo, J. 2013. Interactive Effects of Nitrogen and Phosphorus on Soil Microbial Communities in a Tropical Forest. Plos One, 8(4): 1-10.

Mishra, B., Sharma, A., Singh, S.K., Prasad, J. and Singh, B.P. 2008. Influence of continuous application of amendments to maize - wheat cropping system on dynamics of soil microbial biomass in Alfisol of Jharkhand. J. Indian Soc. Soil Sci., 56(1): 71-75.

Potdar, D.S., Deshmukh, S.U., Rathod, B.G. and Pawar, S.M. 2014. Soil test based targeted yield equations and its validation for preseasonal sugarcane on inceptisol. Int. J. Curr. Res., 6(9): 82738277.

Rajanna, M.P. and Patil, V.C. 2003. Effect of fertigation on yield and quality of sugarcane. Indian Sugar, 52: 10071011.

Raskar, B.S. and Bhoi, P.G. 2001. Productivity of sugarcane as influenced by planting techniques and sources of fertigation under drip irrigation. Indian Sugar, 50: 801- 810.

Zende, G.K. 1998. Efficient use of fertilizers for sugarcane production. In: Convention of Deccan Sugar Technologists Association, Pune, India, pp. 14-17.

\section{How to cite this article:}

Basavaraj Patil, S.M. Hiremath, B.T. Nadagouda and M.P. Potdar. 2017. Impact of Fertigation and Target Yield Levels on Soil Microbial Biomass and Cane Yield of Ratoon Sugarcane. Int.J.Curr.Microbiol.App.Sci. 6(4): 1718-1722. doi: https://doi.org/10.20546/ijcmas.2017.604.206 